Article

\title{
When Spatial Dimension Matters: Comparing Personal Network Characteristics in Different Segregated Areas
}

\author{
Éva Huszti ${ }^{1}$, Fruzsina Albert ${ }^{2,3}$, Adrienne Csizmady ${ }^{2,4}$, llona Nagy ${ }^{2}$ and Beáta Dávid ${ }^{2,3, *}$ \\ ${ }^{1}$ Institute of Political Science and Sociology, Faculty of Humanities, University of Debrecen, Hungary; \\ E-Mail: huszti.eva@arts.unideb.hu \\ 2 Institute for Sociology, Centre for Social Sciences, Hungary; E-Mails: albert.fruzsina@tk.hu (F.A.), \\ csizmady.adrienne@tk.hu (A.C.),nagyilona4918@gmail.com (I.N.), bea.david@ella.hu (B.D.) \\ ${ }^{3}$ Institute of Mental Health, Semmelweis University, Hungary \\ ${ }^{4}$ Department of Sociology, Faculty of Humanities and Social Sciences, University of Szeged, Hungary \\ * Corresponding author
}

Submitted: 14 May 2021 | Accepted: 29 July 2021 | Published: 15 December 2021

\begin{abstract}
Living in segregated areas with concentrated neighbourhood poverty negatively affects the quality of life, including the availability of local jobs, access to services, and supportive social relationships. However, even with similar neighbourhood poverty levels, the degree and structure of spatial separation vary markedly between such areas. We expected that the level of spatial segregation aggravates the social exclusion of its inhabitants by negatively affecting their social capital. To test this hypothesis, we identified three low-income neighbourhoods with high poverty rates (78\%) in a medium-sized town in Hungary, with different levels of integration in the city (based on characteristics such as the degree of spatial separation, infrastructure, and availability of services). The three neighbourhoods were located in two areas of differing degrees of integration in the fabric of the city: fully integrated, semi-integrated (integrated into the surrounding residential area but isolated from the city), and non-integrated. $69 \%$ of the 394 households in these areas were represented in our sample (one respondent per household). We interviewed respondents regarding the size and composition of their personal networks. Our results, which also distinguished between Roma and non-Roma inhabitants, showed that those living in the spatially more integrated area not only have the largest and most diverse networks but seem to have a strong, "bonding-based" cohesive community network as well. Even the non-Roma who live there have ethnically heterogeneous-in other wordsRoma network members. The disintegrated area, on the other hand, is characterised by both spatial and social isolation.
\end{abstract}

\section{Keywords}

bonding and bridging; ethnic homophily; policy intentions; Roma; segregation; social capital; spatial homophily

\section{Issue}

This article is part of the issue "In Good Company? Personal Relationships, Network Embeddedness, and Social Inclusion" edited by Miranda J. Lubbers (Autonomous University of Barcelona, Spain).

(C) 2021 by the authors; licensee Cogitatio (Lisbon, Portugal). This article is licensed under a Creative Commons Attribution 4.0 International License (CC BY).

\section{Introduction}

Social capital is embodied in interpersonal relationships (Bourdieu, 1986; Coleman, 1988; Portes, 1998). The availability of social support is particularly important for poor people since it can decrease the negative impacts of their disadvantaged economic circumstances (Saegert et al., 2001). The stigmatising nature of poverty, together with social networks, that are characterised by homophily (McPherson et al., 2001), result in lower resourcestrength networks, as these networks are more likely to consist of similarly disadvantaged people. Numerous studies have examined the relationship between interpersonal social networks and poverty (Albert \& Hajdu, 2020; Böhnke \& Link, 2017; Eckhard, 2018) and found a negative link between them (e.g., the quantity and 
quality of interpersonal relations). This finding supports the so-called accumulation hypothesis and warns of the "downward spiral of social exclusion" (Mood \& Jonsson, 2016, p. 637).

However, research on social networks and poverty does not always take the spatial context into account. Traditionally, international research has been limited to describe relationships within a well-defined area (e.g., colleges; see Doreian \& Conti, 2012; Faust et al., 1999) or to study the spread of disease (social and spatial clustering of disease; see Emch et al., 2012; Logan et al., 2016). Our study is in the context of urban sociology rather than following these lines of inquiry. Spatial separation and barriers to spatial mobility often hinder social mobility and may result in ethnic segregation. Spatial integration is just as important concerning a stable social position as, for example, labour market integration (Massey, 2001), and we may expect that spatial separation reduces the chances of social integration by marking physical boundaries for inhabitants of segregated areas and thus producing more homogenous interpersonal networks.

In our article, we analyse how the physical and social characteristics of a neighbourhood can shape the structure of the social networks of its residents by analysing the network characteristics of people living in three segregated areas of a medium-sized Hungarian town. We also study whether there are network differences between the non-Roma and the Roma people living together in the same area. We expect that, in general, spatial segregation facilitates the formation of certain ties but hinders others. We suppose that the spatial dimension influences network size and composition more than ethnicity. Our data facilitates the evaluation of how "far" personal networks can reach both spatially and ethnically.

The novelty of our analysis is that it focuses on both the ethnic and spatial homogeneity of the ego-networks in three deprived areas of the same city, which at the same time differ in their level of integration into the city fabric. We found subtle differences concerning the degree of spatial disintegration.

\section{Theoretical Background}

Social relations are an important dimension of social integration (Coleman, 1988; Granovetter, 1985). A lack of social integration does not only mean limited access to resources, but it may also cause anxiety and depression, decrease well-being and lead to increased morbidity and mortality (Putnam, 2000; Wilkinson, 1996).

In terms of integration, bonding and bridging ties function differently. The former creates relatively closed and socio-demographically homogeneous groups with shared resources and information, high levels of intimacy and trust. Weaker but more heterophilic ties with more distant individuals (bridging ties) connect the ego to different social groups, even from greater social distances, contributing to the structural mobility of the individual (Lin, 2008).
Network analysts identify two basic types of homophily: baseline and inbreeding (McPherson et al., 2001). Baseline homophily refers to the fact that we have a limited pool of potential ties defined by our demographic characteristics and foci of activities (e.g., as in our case, ethnicity, or place of residence) and the main source of these ties is geographical space. Inbreeding homophily is conceptualised as any other kind of homophily. As a result, we form and maintain ties more easily with those who are geographically close (Wong et al., 2006). Bidard et al. (2020), building on Fischer (1982), point out that strong ties are more resistant to distance, which means that in general, in personal networks, strong ties are more dispersed in geographic space than weak ties. Those who live in closer proximity have to spend less money and time to meet; thus, supportive ties, which are especially important for the poor, may form faster and more easily and can be maintained over long periods more efficiently (Emch et al., 2012). Proximity remained an important characteristic despite the spread of info-communication technologies (Mok et al., 2004).

Researchers have long studied the relationship between social integration and urban structure. Roberto and Hwang (2017) argue that there is a causal relationship between the physical separation of urban spaces and the formation and sustainment of segregation. People living in areas that are difficult to reach and less integrated into the urban fabric have limited access to transport and urban space, and their social integration is hampered. Physical barriers such as railway tracks, motorways, industrial areas, forests, fences, etc., create clear divisions among various areas. Some of these barriers are natural; others have been created artificially, often to clearly separate deprived areas from those populated by more affluent residents. At the same time, these barriers also physically limit the growth of areas populated by low-status residents not only with regards to the number of available housing units but also the scope of available services, thus sustaining social and spatial isolation and increasing social inequalities.

Tóth et al. (2021) found that the physical arrangement of residential areas in a city is connected to social network fragmentation: Existing inequalities are exacerbated by physical barriers, significant distances, physically concentrated amenities, which make social networks more fragmented. Thus, through social networks, the geographical characteristics of a place compound economic inequalities.

Spatial segregation can also have benefits, including a cohesive community organised on a geographic basis, making it easier to navigate the world and everyday life. However, living in spatially isolated, segregated neighbourhoods and the associated stigma both hinder assimilation (Massey, 2001). According to previous research (see Massey \& Denton, 1988), a high level of segregation isolates minority groups from the services and opportunities that can contribute to raising their quality of life 
to the level of the majority population. Thus, any movement towards concentrating poverty in an isolated neighbourhood increases the likelihood of socio-economic failure within the segregated group (e.g., teenage pregnancy, school dropouts, low educational attainment, low income, criminality, and victimisation). Therefore, municipalities should handle poverty and spatial exclusion together to intervene successfully (Massey, 2001).

Roma people are the most numerous and most disadvantaged ethnic minority groups living in contemporary Central and Eastern Europe, including Hungary. Ethnic identity is considered a private matter, and, for data protection purposes, it is not included in the mandatory national data reporting in Hungary.

According to the 2011 census, the latest available official data on the number of minorities living in Hungary, approximately $3 \%$ of the total population identified themselves as Roma (Központi Statisztikai Hivatal [KSH], 2014). While the widespread stereotypes, attitudes and prejudices concerning the Roma minority suggest the existence of a homogenised group, the actual population meant by the category of Roma varies, not only among the non-Roma majority but also among the Roma. Data on self-categorisation show a smaller number of Roma than data resulting from categorisation set by outgroup members (Csepeli \& Simon, 2004). Thus, it is not possible to measure the size of the Roma population, but it is estimated to be $600,000-700,000$ (Bernát, 2014). The age composition of the Roma population is significantly younger, and their at-risk of poverty and social inclusion index is three times higher compared to the non-Roma population, which means that the majority of Roma people in Hungary are affected by poverty and social exclusion. Roma people have more children, lower education attainment (the share of Roma with at most primary education is still four times the level for non-Roma), and higher unemployment. They tend to live in small settlements, often in less developed regions (Bernát, 2019; European Union Agency for Fundamental Rights, 2016).

Most Roma are concentrated in underdeveloped areas of the country, representing a significant territorial disadvantage (Kertesi, 2005; Nemes Nagy \& Németh, 2005). There are 10 districts of settlements where their ratio is between 30 to $40 \%, 62 \%$ lives in towns and $38 \%$ in villages, primarily in small ones, with a population of less than 2000. In towns, their numbers grow mostly due to immigration. In the villages, their proportion increases due to the out-migration of the non-Roma and their higher fertility rates (Pénzes et al., 2018). In big cities, most of the Roma live in segregated areas.

Based on the most recent available survey result (from 2010) and the last census (from 2011), there were 1633 poor and ethnic ghettoes and segregated areas in Hungary with 280-300 thousand inhabitants, which is $3 \%$ of the Hungarian population. These areas are concentrated in the North-Eastern and Southern regions of the country, to $26 \%$ of its settlements ( 820 municipali- ties and 10 districts of Budapest out of 22). 39\% of these areas are in towns, $2 \%$ in Budapest, the capital city, and $32 \%$ in villages. $20 \%$ of them are in or close to the centre of the settlement, $66 \%$ are on the periphery, and $14 \%$ are outside the settlement limits (Domokos \& Herczeg, 2010). The spatial distribution pattern of the Roma population has remained essentially unchanged since 1980 (Pénzes et al., 2018). The ability or willingness to move is strongly correlated with demographic characteristics, occupation and regional position of residence (Hárs \& Simon, 2015) and financial situation. The Hungarian population is less mobile than the European average (3-4.5\% move house every year). Willingness to move is also low. According to KSH (2016), $79 \%$ of the population do not plan to move. This proportion is slightly higher among Roma (83\%). In fact, they would be willing to move only if there were significant financial benefits (Varga, 2020). Hungary is one of the CEE countries with a private homeownership rate above $90 \%$; Hegedüs et al. (2016) point out that homeownership has a strong attenuating effect on domestic moving decisions.

In Hungary, socially disadvantaged people have very few opportunities to move to a more spatially integrated area. They live in social housing units (mostly municipallyowned) with poor quality. The spatial mobility of Roma has become increasingly limited as the number of social housing units has started to decline significantly since 1990 . The share of these housing units is very low $(2.6 \%$; KSH, 2016).

According to Hungarian studies, although Roma had ethnically homogeneous networks of contacts in the early 2000s, their family ties were stronger, and they had more friends than members of the majority society (Albert \& Dávid, 2006). The ethnically homogeneous network was even more characteristic for those who belonged to an ethnically closed community and identified themselves as Roma (Messing, 2006). However, more recent research reveals a change: Roma people no longer have a richer network of contacts. Their circle of friends has been significantly reduced and has become even more ethnically homogeneous, and the proportion of relatives among their confidants has decreased. Despite improving educational and economic indicators in general, only a small fraction of people established contact resources. Isolation from each other and mainstream society continues to be present (Dávid et al., 2020).

In segregated areas, social network characteristics vary and contribute to sustaining the existing power relations. Some of the few Hungarian studies on the topic highlighted that relational characteristics of poor and deprived segments of the population are quite different in various settings/regions (Dávid, 2010; Messing, 2006; Messing \& Molnár, 2011), which provides the rationale for our study to compare the network characteristics of people living in poverty and social exclusion in different territorial segments of the very same city. Katona et al. (2020), analysing segregated areas in four Hungarian and 
four Romanian settlements, found that the integration of local communities can only be realised if they receive support to build ties to form external contact networks and then they actively use those contacts on their own.

\section{Data and Method}

In 2019, we surveyed the living conditions in two segregated areas of a Hungarian city, which included a detailed module on interpersonal network characteristics. According to Government Decree 314/2012 (8.XI), "a segregated area or an area at risk of segregation [is] a contiguous area where families of low social status are concentrated or show signs of social status decline, and therefore community intervention is required in the area" (NYITS, 2014, p. 44). The identification of segregated areas was based on the segregation indicator (the proportion of people of working age with no more than primary education and no regular income from work) produced from the 2011 census data of the $\mathrm{KSH}$ (total number of segregated areas is 1633 , where $280,000-300,000$ people, roughly $3 \%$ of the total population, live).

Interviewers reached 271 households in these two segregated areas (S\#1 and S\#2). The number of social housing units owned by the local government in these two areas is 394 (131 in S\#1, 263 in S\#2), with a total population of 1374 people (525 in S\#1, 849 in S\#2; see Nyíregyháza City Integrated Settlement Development Strategy, 2014). Based on this, and considering the number of housing units, the response rate was high (Huszti, 2019; Takács \& Huszti, 2019). We analyse our data in three main dimensions: spatial, network, ethnicity.

\subsection{The Areas in Focus}

The segregated areas in our study are situated far from the city centre, occupy relatively small space, and are far from each other (see Figure 1). Most of the apartments are social housing units with relatively low rent owned by the local government. Both areas are marked by mediumlevel ethnic segregation (with a mix of Roma and nonRoma poor population), but they have different potentials regarding social integration.

As shown in Figure 1, the smaller S\#1 is less isolated; therefore, we label it as spatially integrated. It is only $1.5 \mathrm{~km}$ away from the city centre, situated between two main roads, near the former city limits. Despite the development of the city and the wider neighbourhood, its segregated character remained. Given its location along main roads, residents have good transportation access to public services. The bus service is frequent and regular, and the inner city can be accessed by bicycle. The 4-flat housing units were built in the early 1960s with minimal conveniences. They are still without any modern amenities. They only have electricity and are in a very run-down condition. Households have the most members in this area, with an average of 4-6 people per household and 2-4 people per room. The surrounding public roads are in good shape but getting around within the area among the buildings is more problematic since there is no rainwater drainage system. Inhabitants predominantly have low educational attainment, which limits their employment opportunities. As the city centre and another housing estate are close by, several educational institutions are available. General practitioners are available in the city centre, outpatient clinics and emergency care are only a couple of minutes away. Social workers and district nurses are actively present.

The larger segregated area (S\#2) became part of the city fabric after the 1850s; it primarily functioned as a military base for cavalry. Its population changed in the 1960s; the more affluent military and administrative elite were replaced by Roma people moving into the city.

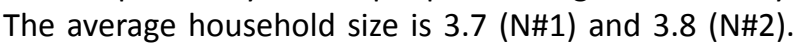
The average density is $3.4(\mathrm{N \# 1})$ and $3.2(\mathrm{N \# 2})$ people per

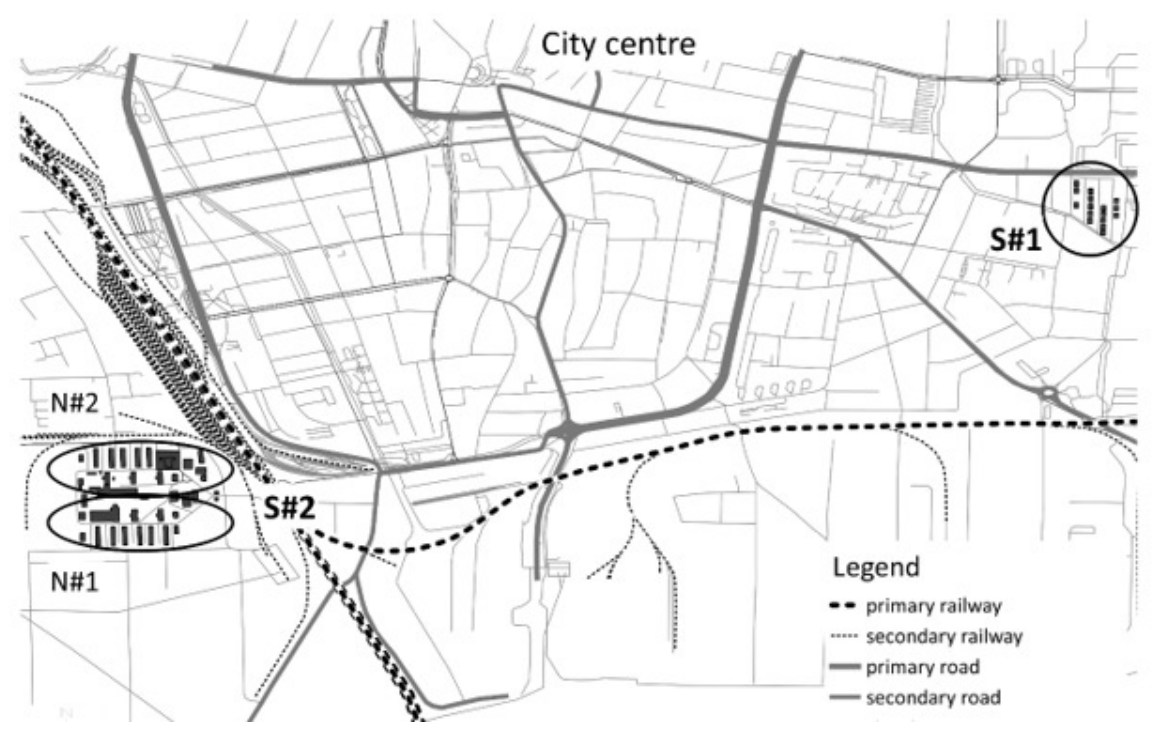

Figure 1. Segregated areas (S\#1 and S\#2) and different neighbourhoods (N\#1 and N\#2) within S\#2. 
room. The segregated nature of the area is well-indicated by its spatial characteristics: The railway lines separate it from the major parts of the city, the neighbouring, more modern city area can only be accessed on foot. Public services provision can be considered good, as there is a crèche, kindergarten, and primary school in the area. However, children from S\#2 attend these mostly. It is also possible to send children to other educational institutions in the city. Family and child welfare services are available locally, together with day-care provision for the old. Various social, healthcare, religious, and civil organisations provide in-kind support for the inhabitants.

Within S\#2, we identified two neighbourhoods based on various characteristics (the degree of spatial separation, infrastructure, availability of services, etc.) as shown in Figure 1. The spatially semi-integrated neighbourhood ( $\mathrm{N \# 1)}$ is more integrated into the surrounding residential area but isolated from the city. The spatially non-integrated neighbourhood (N\#2) is less integrated, as the railway cuts off direct transit routes to other areas on three sides of the area, and only one street connects it to the rest of the city. Spatially it is well-separated from the semi-integrated part. It is closed off from other residential areas by the railways and industrial plants on the northern side.

\subsection{Social Capital: Bonding and Bridging Ties}

We consider confiding relations to be bonding ties, which we elicited by a core discussion network-generated question (McCallister \& Fischer, 1978). The following namegenerator was applied: "Most people sometimes discuss important matters with others. If you consider the past 12 months, who are the people with whom you discussed the most important things, your problems, sorrows, complaints (e.g., personal and/or family matters, questions concerning work, etc)?"

We followed up by asking questions concerning the listed alters, including gender, age, educational attainment, type of relationship, length of knowing each other, living distance, type of support given, and ethnicity. The maximum number of alters was limited to five. In the analysis, we focus on the kin and non-kin composition of these networks and their ethnic and spatial characteristics. We consider weak ties (Granovetter, 1973) to be bridging ties, which we elicited by a position generator containing 30 different occupations: actor/actress, administrator, banker, chief executive, civil welfare office administrator, clerical officer in local government, dress shop owner, driver, engineer, entrepreneur, farmworker, hairdresser, health visitor, housing administrator, interior designer, journalist, NGO worker, nurse, paediatrician, politician, sales/shop assistant, scientist, security guard, skilled worker, social worker, solicitor, surgeon, teacher (secondary), unskilled worker, waiter.

If the respondent knew somebody with the named occupation, we asked the person's gender, if they lived in the same area, and their ethnicity (Lin \& Dumin, 1986).
In the analysis, we include the number of weak ties and their ethnic and spatial characteristics.

\subsection{Ethnicity}

Csepeli and Simon (2004, p. 134) wrote:

There are two theoretical ways of Gypsy identity construction: as an imposed and as an adopted identity, i.e., the labels used by the majority or as a procedure of self-identification performed by the Gypsies themselves, based on their being culturally different.

For our research purposes, we defined Roma ethnicity based on self-identification.

Based on Leszczensky and Pink (2019), we considered the relationships ethnically homogeneous if the respondent identified himself as Roma and described the other person identified as Roma as well. We also considered the relationships ethnically homophilic where the respondent did not identify himself as Roma and described the other person identified as not being Roma.

\subsection{Empirical Strategy}

We examined whether there is a difference between segregated areas according to network characteristics taking into account socio-demographic control variables. Since these control attributions generally do not have a significant effect on dependent variables, we analysed the links between network characteristics and place of residence using discriminant analysis. We calculated the percentage that our dependent variable, living in one of the segregated areas, can be estimated by the independent variables. Since bigger and more diverse interpersonal networks may enhance social integration more effectively, we tested whether those living in a spatially more integrated area are more integrated socially based on their interpersonal network characteristics. The variables we included in our analysis are core discussion network size, number of weak ties, rate of ethnic and spatial homogeneity, ego's ethnicity, and the length of residence in the given area.

\section{Results}

\subsection{Description of the Segregated Areas}

$68.6 \%$ of the sample are women: $45.7 \%$ are at most 40 years old and the average age is 43.5 years. The rate of women is higher in $\mathrm{N \# 2} \mathrm{(74 \% )} \mathrm{than} \mathrm{in} \mathrm{the} \mathrm{other} \mathrm{two} \mathrm{areas.}$ The rate of ages 40 years or younger is higher in $\mathrm{N \# 1}$ and

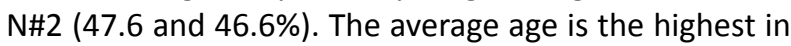
$\mathrm{N \# 2}$ (45.2 years). Most of the sample have low educational attainment. $77.3 \%$ has at most primary school education ( 8 years of schooling). The share of those with a higher educational level than primary school is the highest in N\#2 (28.8\%). $67.9 \%$ of the sample did not work 
at the time of data collection. There is no significant difference among the three surveyed areas in terms of sex, age, educational attainment, and economic activity.

The analysed population is a homogenous group based on their basic socio-demographic characteristics, but there are significant differences based on ethnic composition and length of residence (see Table 1). The overall rate of Roma respondents is $57.9 \%$, but it is significantly lower in $\mathrm{N \# 2} \mathrm{(41.1 \% )} \mathrm{compared} \mathrm{to} \mathrm{the} \mathrm{other} \mathrm{two} \mathrm{areas.}$ A total of 19 (only $7 \%$ of the total sample) were born in the area, the highest rate is in area S\#1 among Roma residents. Residents in S\#1 have lived there on average for 21.9 years, while in $\mathrm{N \# 1}$ for 12.6 and $\mathrm{N \# 2}$ for 9.9 years.

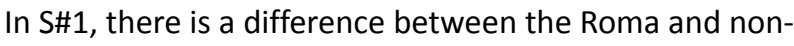
Roma population: the Roma moved there at a younger age than the non-Roma (18.1 vs. 26.5 years).

\subsection{Social Capital}

\subsubsection{The Number and Composition of Bonding Ties}

Respondents, on average, mentioned 1.41 bonding ties in the core discussion network name-generator situation $(\min 0 ; \max 5)$. In line with our expectations, those living in the spatially more integrated area have significantly more ties (on average 2) than those from $\mathrm{N \# 1}$ $(1.23, p<0,001)$ and $N \# 2(1.16, p=0,001)$. There is a difference within the areas regarding ethnicity. In the spatially non-integrated part (N\#2), Roma respondents had fewer bonding ties than the non-Roma (1.00 vs. 1.28 ; see Table 2).

We found no statistically significant differences regarding the number of bonding ties concerning the sex,

Table 1. Some characteristics of respondents $(N=271)$.

\begin{tabular}{|c|c|c|c|}
\hline & $\begin{array}{c}\text { S\#2 } \\
\text { S\#1 } \\
(n=70)\end{array}$ & $\begin{array}{c}N \# 1 \\
(n=128)\end{array}$ & $\begin{array}{c}N \# 2 \\
(n=73)\end{array}$ \\
\hline & $\%$ & $\%$ & $\%$ \\
\hline \multicolumn{4}{|l|}{ Ethnicity } \\
\hline Non-Roma & 34.29 & 36.72 & 58.90 \\
\hline Roma & 65.71 & 63.28 & 41.10 \\
\hline \multicolumn{4}{|l|}{ Born in area } \\
\hline Non-Roma & 12.50 & 2.10 & 0.00 \\
\hline \multirow[t]{2}{*}{ Roma } & 26.10 & 3.70 & 0.00 \\
\hline & Mean & Mean & Mean \\
\hline Length of residence in the given area & 21.96 & 12.55 & 9.97 \\
\hline Non-Roma & 22.79 & 13.64 & 10.14 \\
\hline Roma & 21.52 & 11.91 & 9.72 \\
\hline At what age the respondent moved to the given area & 21.09 & 30.59 & 35.27 \\
\hline Non-Roma & 26.50 & 30.00 & 36.26 \\
\hline Roma & 18.14 & 30.94 & 33.83 \\
\hline
\end{tabular}

Note: All effects are significant at $p<0.05$.

Table 2. Size and composition of bonding ties

\begin{tabular}{|c|c|c|c|c|}
\hline & & & S\#2 & \\
\hline & & $\begin{array}{c}\text { S\#1 } \\
(n=70)\end{array}$ & $\begin{array}{c}N \# 1 \\
(n=128)\end{array}$ & $\begin{array}{c}N \# 2 \\
(n=73)\end{array}$ \\
\hline & & Mean & Mean & Mean \\
\hline Bonding ties & & 2.00 & 1.23 & 1.16 \\
\hline Non-Roma & & 1.75 & 1.30 & 1.28 \\
\hline Roma & & 2.13 & 1.19 & 1.00 \\
\hline & & $\%$ & $\%$ & $\%$ \\
\hline Composition of bonding ties & 0 kin 0 non-kin & 20.00 & 10.16 & 24.66 \\
\hline Only kin & & 50.00 & 75.00 & 50.68 \\
\hline Only non-kin & & 14.29 & 10.94 & 13.70 \\
\hline Mix & & 15.71 & 3.91 & 10.96 \\
\hline
\end{tabular}

Note: All effects are significant at $p<0.05$. 
age, educational attainment, and economic activity status of the egos.

When analysing the composition of the bonding ties, we differentiated four groups: Respondent has (1) no bonding ties, (2) only kin bonding ties, (3) only non-kin bonding ties, and (4) both kin and non-kin ties (see Table 2). We found a significant difference in this composition by residential area $(p=0,002)$. The share of those with no bonding ties was the highest among those living in N\#2 (24.7\%). The most diverse, "mixed" composition was most prevalent in S\#1 (15.7\%). The highest rate of people with only kin bonding ties was found in N\#1 (75\%).

\subsubsection{Ethnic and Spatial Homophily of Bonding Ties}

Table 3 shows that the bonding ties of the Roma are ethnically and residentially more homogenous than those of the non-Roma, irrespective of their place of residence. For non-Roma respondents, we found a significant difference in in the three areas: The core networks are ethnically more homogenous in the non-integrated neighbourhood (N\#2, 67.59\%) and the most heterogeneous in the case of the non-Roma living in the integrated area (S\#1, 25.69\%). The ethnic homophily of the core networks of the Roma and non-Roma is quite different in S\#1: The core networks of the non-Roma are ethnically heterogeneous, while those of the Roma are homogenous.

Most of the alters live in the same area as the ego, that is, they are spatially very close, either from the same household, street, or at least from the same segregated part of the settlement. This is most pronounced for those

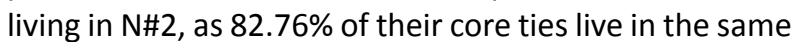
area. There is a significant difference between the Roma and non-Roma in S\#1: Non-Roma have more spatially and more heterogeneous bonding ties and several ties that live further away, while Roma have more ties to their residential area (see Table 3).
4.2.3. The Number, Ethnic, and Spatial Homophily of Bridging Ties

Respondents have an average of 8.43 weak ties, which is significantly influenced by their age and activity status. First, younger respondents (those younger than 40 years old) have more bridging ties than older respondents ( 9.58 vs. 7.57 persons, $p=0.003$ ); and second, those who were employed at the time of data collection have more weak ties than those who did not have a job (9.53 vs. 7.91 people, $p=0.067$ ).

There are significant differences in the number of bridging ties among the three areas (see Table 4): On average, respondents from $\mathrm{N \# 1}$ had the most ties (9.71) and those from N\#2 the fewest (6.21). This is true for both the Roma and non-Roma. We found no statistically significant differences within the areas between the Roma and non-Roma, although Roma people tend to have more bridging ties in all three areas (see Table 4).

There is no difference based on which area they live in for non-Roma as far as the ethnic homophily of weak ties is concerned. Non-Roma have predominantly non-Roma weak ties, which is not that surprising since non-Roma people are over-represented in the occupations listed in the position generator. The ethnically homogenous ties of the non-Roma poor may enhance their social integration. In the case of the Roma, there is a significant difference in their bridging ties based on which area they live in. Roma people living in S\#1 have the smallest proportion of Roma weak ties (13.14\%). Thus, their more extended network is ethnically heterogeneous, containing a large number of non-Roma people, indicating greater social integration. In this respect,

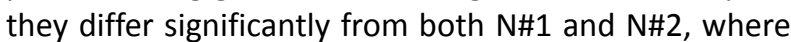
the share of Roma weak ties is higher (34.2 and 31.76\%). The spatial heterogeneity of bridging ties is more pronounced for those living in S\#1, in other words, their weak ties are the most spatially dispersed, and for those living in N\#1, they are the most homogenous, limited to their residential area.

Table 3. Ethnic and spatial homophily of bonding ties.

\begin{tabular}{|c|c|c|c|}
\hline & $\begin{array}{c}\text { S\#1 } \\
(n=70)\end{array}$ & $\begin{array}{c}\mathrm{S} \# 2 \\
\mathrm{~N} \# 1 \\
(\mathrm{n}=128)\end{array}$ & $\begin{array}{c}N \# 2 \\
(n=73)\end{array}$ \\
\hline & $\%$ & $\%$ & $\%$ \\
\hline Ethnic homophily & 64.79 & 69.42 & 72.42 \\
\hline Non-Roma & 25.69 & 60.61 & 67.59 \\
\hline Roma & 81.84 & 74.88 & 81.58 \\
\hline Residential homophily & 74.82 & 75.51 & 82.76 \\
\hline Non-Roma & 63.43 & 71.97 & 79.91 \\
\hline Roma & 79.79 & 77.70 & 88.16 \\
\hline
\end{tabular}

Note: All effects are significant at $p<0.05$. 
Table 4. Network characteristics of bridging ties.

\begin{tabular}{|c|c|c|c|}
\hline & $\begin{array}{c}\text { S\#1 } \\
(n=70)\end{array}$ & $\begin{array}{c}\text { S\#2 } \\
N \# 1 \\
(n=128)\end{array}$ & $\begin{array}{c}N \# 2 \\
(n=73)\end{array}$ \\
\hline & Mean & Mean & Mean \\
\hline Number of bridging ties & 8.41 & 9.71 & 6.21 \\
\hline Non-Roma & 7.54 & 8.85 & 5.77 \\
\hline \multirow[t]{2}{*}{ Roma } & 8.87 & 10.21 & 6.83 \\
\hline & $\%$ & $\%$ & $\%$ \\
\hline Ethnic homophily & 38.16 & 50.81 & 67.84 \\
\hline Non-Roma & 87.80 & 78.48 & 87.57 \\
\hline Roma & 17.43 & 35.52 & 39.93 \\
\hline Residential homophily & 14.47 & 29.37 & 23.68 \\
\hline Non-Roma & 17.47 & 20.64 & 17.97 \\
\hline Roma & 13.14 & 34.20 & 31.76 \\
\hline
\end{tabular}

Note: All effects are significant at $p<0.05$.

\subsection{Spatial Segregation and Social Capital}

We analysed the links between the structure of social networks and the level of spatial integration using discriminant analysis. Classification results show that $69.3 \%$ of the cases from the original three neighbourhoods were correctly classified by linear discriminant functions, which, in fact, indicates a strong relationship between the two types of integration. The first distributed function explains $77.5 \%$ and the second $22.5 \%$ of the explained variance between groups $(p<0,001)$.

The first function (see Table 5 ) is where positive values embody several bonding ties, a long period of residence in the given area and spatially heterogeneous bridging social capital. The second function is where pos- itive values refer to richness in bridging social capital, the dominance of ethnically heterogeneous weak ties and the Roma ethnicity of the respondents. The first function indicates some kind of local embeddedness, thus named "bonding-based non-Roma and Roma," while the second, characterised by the heterogeneous bridging ties of the Roma, is called "bridging-based Roma."

The three group centroids are significantly different from each other (see Table 6 and Figure 2). The spatially more integrated area (S\#1) is characterised dominantly by the first function: several bonding ties, strong attachment to the area (living there for the longest time), and spatially heterogeneous bridging ties. The so-called "bridging-based Roma" function mostly characterises the spatially semi-integrated neighbourhood (S\#2 N\#1)

Table 5. Structure matrix of the discriminant analysis.

\begin{tabular}{lrr}
\hline & Function 1 & Function 2 \\
\hline Number of bonding ties & 0.65 & -0.12 \\
Length of residence & 0.52 & 0.25 \\
Spatial homophily of bridging ties & -0.34 & 0.20 \\
Ethnic homophily of bonding ties & -0.06 & -0.05 \\
Number of bridging ties & 0.00 & 0.61 \\
Ethnic homophily of bridging ties & -0.32 & -0.56 \\
Ethnicity of ego & 0.19 & 0.55 \\
Spatial homophily of bonding ties & -0.05 & -0.16 \\
\hline
\end{tabular}

Table 6. The discriminant functions in the three areas studied.

\begin{tabular}{|c|c|c|c|}
\hline & & \multicolumn{2}{|c|}{ Functions at group centroids } \\
\hline & & Bonding-based non-Roma and Roma & Bridging-based Roma \\
\hline S\#1 & & 1.401 & 0.050 \\
\hline \multirow{2}{*}{ S\#2 } & N\#1 & -0.510 & 0.334 \\
\hline & N\#2 & -0.379 & -0.738 \\
\hline
\end{tabular}




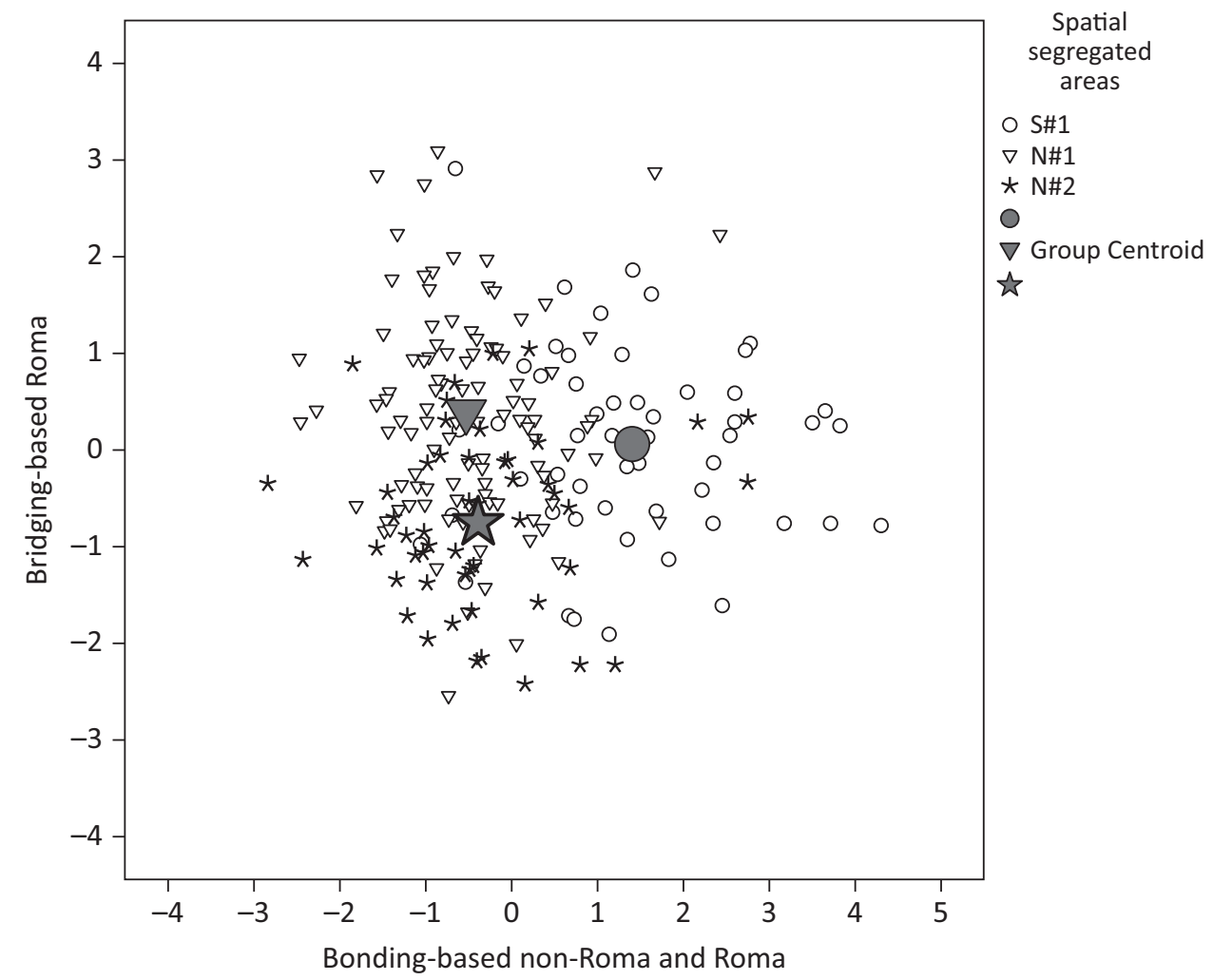

Figure 2. Plot of discriminant functions.

where mostly the Roma respondents are the ones who have more numerous bridging ties, preferably non-Roma and locally bounded. In this neighbourhood, the "bonding-based non-Roma and Roma" function is the weakest. The spatially non-integrated neighbourhood (S\#2 N\#2) is where the first function is also weak, along with an extremely disadvantaged position on the "Bridging-based Roma function": Most of these respondents are socially isolated from the fabric of the city.

\section{Conclusion}

The population groups in our analysis do not differ in the three areas based on their socio-demographic characteristics, yet the characteristics of their social networks differ in meaningful ways. Moreover, even inside a seemingly homogenous spatially segregated area (S\#2), we may find significant differences regarding social capital. Those living in the more spatially integrated area (S\#1) have the most bonding ties, and the number of these ties decreases with the level of spatial integration of the given area. Ethnic differences are also clearly visible: the Roma in the spatially non-integrated part (N\#2) have fewer bonding ties than the non-Roma. Those living in the spatially non-integrated area (N\#2) are the most bounded locally.

The number of bridging weak ties varies greatly by space and ethnicity: Those from the spatially semiintegrated area (N\#1) have the most, while those in the spatially non-integrated area (N\#2) the fewest.
Roma respondents tend to have more weak ties than non-Roma respondents. The number of weak ties of non-Roma respondents does not differ spatially by the area in which they live. However, in the case of the Roma, the network of those living in the spatially integrated area (S\#1) is more diverse both ethnically and spatially; that of the spatially semi-integrated area $(\mathrm{NH1})$ is more locally bounded. The discriminant analysis supports our original claim. The level of spatial integration matters and is reflected in the characteristics of the interpersonal network structures: Those living in more spatially integrated, less segregated areas have somewhat larger, more spatially and ethnically diverse networks, both in terms of their strong and weak ties, while the opposite is true for those living in less integrated and most segregated areas. Those who live in the spatially semiintegrated area (N\#1) are "halfway" in both respects: Their mostly kin-based core networks are supplemented with wide but predominantly locally bound weak ties.

Although we could detect relevant differences, the populations of all three segregated areas are primarily locally bounded, segregated communities and are much less spatially integrated than other residential areas of the city. Those living in the spatially more integrated area (S\#1) not only have the largest and most diverse networks but also seem to have a strong, "bonding-based" cohesive community network as well. Even the non-Roma who live there have ethnically heterogeneous, that is, Roma network members. The disintegrated area ( $\mathrm{S \# 2}$ ) is characterised by both spatial and 
social isolation; the network resources of the population cannot enhance their social integration as their spatial exclusion coincides with their social exclusion. Moreover, it seems that even the neighbourhood cannot function as a community.

The survey was part of a project initiated by the local government aiming to ensure the social inclusion of people at risk of social exclusion at the community and individual levels. Specific objectives, such as strong community cohesion at the neighbourhood and municipal levels, promoting social inclusion, overcoming long-term disadvantages for children and increasing access to public services, guide the implementation of the project. The city's long-term plans include the eradication of S\#1 and the creation of a habitable housing environment and increased opportunities for social inclusion in S\#2.

The project staff will build on the existing resources of the population, taking into account the principle of "do no harm" (Charancle \& Lucchi, 2018) to local social resources. In light of the foregoing, our policy recommendation for local urban planning authorities is to consider that populations in segregated areas may have different needs based on their different network resources. The more deprived and spatially and socially segregated area (S\#2) has nothing to build on, while the more spatially integrated area (S\#1) has resources both within the community and "external" links that could be exploited for more efficient social integration.

The positive or negative qualities of the existing relations should be taken into account in executing a move from the part of the settlement with poorer infrastructure (\#S1) to a more modern and comfortable area (S\#2). The more favourable network indicators of the territorially integrated part of the settlement (S\#1) should be considered when the settlement is dismantled: Strong family and neighbourhood ties should be prioritised as potential resources when they are moved to the new residential area. To ensure a positive outcome and avoid conflicts, these should be built upon as a priority in neighbourhood and community activities. Both the strong local cohesion and the change in perspective are well illustrated by the fact that people in settlement S\#1 were initially reluctant to move, despite the promise of better housing. However, currently, those who have not yet moved are looking forward to the move and taking their children to see their new home. The desire to move also reflects the importance of strong ties: People are keen to move to where their trusted relationships and familiar support system are located.

In the other part of the settlement (S\#2), in addition to infrastructural improvements, efforts should be made to increase the network resources of the population, to promote the development and maintenance of core relationships, and to raise awareness among the programme staff of their significant role as bridging ties in the social integration of the inhabitants of the settlement. The number, geographical extent and ethnic composition of core and weak-ties of the people living in the settlement area are also increased and enriched by the community activities organised as part of the project (joint landscaping, joint organisation of events, sports events with members of the majority community, the storytelling-based "Meséd" programme, Lego building), neighbourhood discussions, involvement in training courses and activities.

The COVID epidemic and the resulting restrictions have disrupted community activities and slowed the hard-won progress. The effectiveness of the programme and the organised activities, the involvement of residents and their need for social interaction is reflected in the fact that the May 2021 opening was eagerly awaited by the inhabitants of the municipality. Thus, the programme can rely on the results achieved before the onset of the COVID epidemic and continue effectively.

\section{Acknowledgments}

The research was supported by the National Research, Development and Innovation Office-NKFIH, K124940, and the Közösen a Kiútért (Together for Integration) project no.: TOP-6.9.1-16-NY1-2017-00001.

\section{Conflict of Interests}

The authors declare no conflict of interest.

\section{References}

Albert, F., \& Dávid, B. (2006). A kapcsolati tőke dimenziói etnikai metszetben [Social capital on the basis of ethnicity]. In T. Kolosi, I. G. Tóth, \& G. Vukovich (Eds.), Társadalmi riport 2006 [Social report 2006] (pp. 351-369). TÁRKI. http://www.tarsadalomkutatas.hu/ kkk.php?TPUBL-A-716/publikaciok/tpubl_a_716.pdf

Albert, F., \& Hajdu, G. (2020). Association between poverty indicators and social relations. Journal of Poverty and Social Justice, 28(3), 401-423. https:// doi.org/10.1332/175982720X15966472176159

Bernát, A. (2014). Leszakadóban: A romák társadalmi helyzete a mai Magyarországon [Lagging behind: The social status of the Roma in Hungary]. In T. Kolosi \& I. G. Tóth (Eds.), Társadalmi riport 2014 [Social report 2014] (pp. 248-264). TÁRKI. https://www.tarki.hu/ adatbank-h/kutjel/pdf/b333.pdf

Bernát, A. (2019). Integration of the Roma in Hungary in the 2010s. In I. G. Tóth (Ed.), Társadalmi riport 2019 [Social report 2019] (pp. 195-215). TÁRKI. http://www.tarki.hu/sites/default/files/201902/196_214_Bernat.pdf

Bidard, C., Degenne, A., \& Grossetti, M. (2020). Living in networks: The dynamics of social relations. Cambridge University Press. https://doi.org/10.1017/ 9781108882391

Böhnke, P., \& Link, S. (2017). Poverty and the dynamics of social networks: An analysis of German panel data. European Sociological Review, 33(4), 615-632. 
https://doi.org/10.1093/esr/jcx063

Bourdieu, P. (1986). The forms of capital. In J. Richardson (Ed.), Handbook of theory and research for the sociology of education (pp. 241-258). Greenwood.

Charancle, J. M. B., \& Lucchi, E. (2018). Incorporating the principle of "do no harm": How to take action without causing harm. Humanity \& Inclusion; F3E. https://www.alnap.org/system/files/content/ resource/files/main/donoharm_pe07_synthesis.pdf

Coleman, J. S. (1988). Social capital in the creation of human capital. American Journal of Sociology, 94, S95-S120. http://doi.org/10.1086/228943

Csepeli, G., \& Simon, D. (2004). Construction of Roma identity in Eastern and Central Europe: Perception and self-identification. Journal of Ethnic \& Migration Studies, 30(1), 129-150. http://dx.doi.org/10.1080/ 1369183032000170204

Dávid, B. (2010). Társas kapcsolatok-A kirekesztődés dimenziói [Social relations-Dimensions of exclusion]. In A. Kóczé (Ed.), Nehéz sorsú asszonyok feketén-fehéren: Roma nők munkaerő-piaci és megélhetési lehetöségei két kistérségben [Disadvantaged women in black and white: Roma women's labour market situation and possibilities to make ends meet in two micro regions] (pp. 95-113). MTA Etnikainemzeti Kisebbségkutató Intézet.

Dávid, B., Komolafe, C., Lukács, J. Á., Schutzmann, R., \& Tóth, G. (2020). Hol vannak a testvérek? A roma barátságok alakulása 2004-ben és 2019-ben [Where are the siblings? Roma friendship patterns in 2004 and 2019]. Socio.hu, 10(3). https://doi.org/ 10.18030/socio.hu.2020.3.70

Domokos, V., \& Herczeg, B. (2010). Terra Incognita: Magyarországi szegény-és cigánytelepek felméréseElső eredmények [Terra incognita: A survey on slums and segregated settlement parts inhabited by poor and Roma people-First results]. Szociológiai Szemle, 20(3), 82-99.

Doreian, P., \& Conti, N. (2012). Social context, spatial structure and social network structure. Social Networks, 34(1), 32-46. https://doi.org/10.1016/ j.socnet.2010.09.002

Eckhard, J. (2018). Does poverty increase the risk of social isolation? Insights based on panel data from Germany. The Sociological Quarterly, 59(2), 338-359. https://doi.org/10.1080/00380253.2018.1436943

Emch, M., Root, E. D., Giebultowicz, S., Ali, M., PerezHeydrich, C., \& Yunus, M. (2012). Integration of spatial and social network analysis in disease transmission studies. Annals of the Association of American Geographers, 102(5). https://doi.org/10.1080/ 00045608.2012.671129

European Union Agency for Fundamental Rights. (2016). Second European Union Minorities and Discrimination Survey Roma: Selected findings. http://fra. europa.eu/en/publication/2016/eumidis-iiromaselected-findings

Faust, K., Entwisle, B., Rindfuss, R. R., Walsh, S. J., \&
Sawangdee, Y. (1999). Spatial arrangement of social and economic networks among villages in Nang Rong District, Thailand. Social Networks, 21(4), 311-337. https://doi.org/10.1016/S0378-8733(99)00014-3

Fischer, C. S. (1982). To dwell among friends: Personal network sin town and city. The University of Chicago Press.

Granovetter, M. (1985). Economic action and social structure: The problem of embeddedness. American Journal of Sociology, 91(3), 481-510.

Granovetter, M. S. (1973). The strength of weak ties. American Journal of Sociology, 78, 1360-1380.

Hárs, Á., \& Simon, D. (2015). A munkaerő-migráció változása a kétezres években Magyarországon [Labour force and migration changes around the millennium in Hungary]. In Z. Blaskó \& K. Fazekas (Eds.), Munkaeröpiaci Tükör 2015 [Labour force reflections] (pp. 96-104). MTA KRTK. https://kti.krtk.hu/file/ download/mt_2015_hun/egyben.pdf

Hegedüs, J., Horváth, V., \& Somogyi, E. (2016). A magánbérlakás-szektor múködése és lehetséges szerepe a közösségi lakáspolitikában-A szociális lakásvállalatok koncepciója [The role of the private housing sector in community housing-Social housing concept]. Esély, 2016(2), 29-60.

Huszti, É. (2019). Telepi kapcsolatok [Social network in segregated neighborhoods]. Acta Medicinae et Sociologica, 10(29), 115-130.

Katona, N., Somogyi, E., Teller, N., Tönkö, A., \& Hegedüs, J. (2020). Megérkezés és elköteleződés. Négy hazai és négy romániai testvértelep élete a Jelenlét programban [Arrival and commitment. Life in four Hungarian and Romanian segregated settlement pairs in the "presence" programme]. Metropolitan Research Institute. https://mri.hu/wp-content/uploads/2021/ 02/TF_\%C3\%96sszefoglal\%C3\%B3_tanulm\%C3\% A1ny.pdf

Kertesi, G. (2005). Roma foglalkoztatás az ezredfordulón -A rendszerváltás maradandó sokkja [Roma work structures around the millennium-Permanent impact of the political transition]. Szociológiai Szemle, 15(2), 57-87.

Központi Statisztikai Hivatal. (2014). 2011. Évi népszámlálás. 9.: Nemzetiségi adatok [2011 census. 9: Minority data]. http://www.ksh.hu/docs/hun/xttp/ idoszaki/nepsz2011/nepsz_09_2011.pdf

Központi Statisztikai Hivatal. (2016). Miben élünk-A 2015. Évi lakásfelmérés föbb eredményei [Where do we live-Main results of the housing survey in 2015] http://www.ksh.hu/docs/hun/xttp/idoszaki/ pdf/miben_elunk15.pdf

Leszczensky, L., \& Pink, S. (2019). What drives ethnic homophily? A relational approach on how ethnic identification moderates preferences for sameethnic friends. American Sociological Review, 84(3), 394-419. https://doi.org/10.1177/0003122419846 849

Lin, N., \& Dumin, M. (1986). Access to occupations 
through social ties. Social Networks, 8(4), 365-385.

Lin, N. (2008). A network theory of social capital. In D. Castiglione, J. W. van Deth, \& G. Wolleb (Eds.), The handbook of social capital (pp. 50-69). Oxford University Press.

Logan, J. J, Jolly, A. M., \& Blanford, J. I. (2016). The sociospatial network: Risk and the role of place in the transmission of infectious diseases. PLOS ONE, 11(2). https://doi.org/10.1371/journal.pone.0146915

Massey, D. S. (2001). Residential segregation and neighborhood conditions in U.S. metropolitan areas. In N. J. Smelser, W. J. Wilson, \& F. Mitchell (Eds.), America becoming: Racial trends and their consequences (Vol. 1, pp. 391-434). National Academy Press. https://doi.org/10.17226/9599

Massey, D. S., \& Denton, N. A. (1988). The dimensions of residential segregation. Social Forces, 67(2), 281-315.

McCallister, L., \& Fischer, C. S. (1978). A procedure for surveying personal networks. Sociological Methods and Research, 7, 131-148.

McPherson, M., Smith-Lovin, L., \& Cool, J. M. (2001). Birds of a feather: Homophily in social networks. Annual Review of Sociology, 27, 415-444.

Messing, V. (2006). Lyukakból szőtt háló: Háztartások közötti támogató kapcsolatok roma és nem roma szegények körében [Net woven from holes: Interhousehold supportive relations among Roma and non-Roma poor households]. Szociológiai Szemle, 2006(2), 37-54.

Messing, V., \& Molnár, E. (2011). Bezáródó kapcsolati hálók: Szegény roma háztartások kapcsolati jellemzői [Closing social networks: Characteristics of networks among poor Roma households]. Esély, 2011(5), 47-74.

Mok, D., Wellman, B., \& Basu, R. (2004). Does distance matter for relationships? [Paper presentation]. SUNBELT International Social Network Conference, Portoroz, Slovenia

Mood, C., \& Jonsson, J. O. (2016). The social consequences of poverty: An empirical test on longitudinal data. Social Indicators Research, 127. http://doi.org/ 10.1007/s11205-015-0983-9

Nemes, N. J., \& Németh, N. (2005). Az átmeneti és az új térszerkezet tagoló tényezői [Dividing factors of transitional and new spatial structures]. In K. Fazekas (Ed.), A hely és a fej. Munkapiac és regionalitás Mag- yarországon [The place and the head. Labour market and regionality in Hungary] (pp. 75-137). MTA KTI

NYITS. (2014). Nyíregyháza city integrated settlement development strategy. http://varoshaza.nyiregyhaza. hu/lib/rend_terv/its/170426_2014_2020_its_1mod. pdf

Pénzes, J., Tátrai, P., \& Pásztor, I. Z. (2018). A roma népesség területi megoszlásának változása Magyarországon az elmúlt évtizedekben [Changes in the spatial distribution of the Roma population in Hungary during the last decades]. Területi Statisztika, 58(1), 3-26. https://doi.org/10.15196/TS580101

Portes, A. (1998). Social capital. Its origins and applications in modern sociology. Annual Review of Sociology, 24, 1-24.

Putnam, R. D. (2000). Bowling alone: The collapse and revival of American community. Simon \& Schuster.

Roberto, E., \& Hwang, J. (2017). Barriers to integration: Physical boundaries and the spatial structure of residential segregation. arXiv. https://arxiv.org/ftp/ arxiv/papers/1509/1509.02574.pdf

Saegert, S., Phillip Thompson, J., \& Warren, M. R. (2001). Social capital \& poor communities. Russell Sage Foundation.

Takács, P., \& Huszti, É. (2019). A nyíregyházi Huszár-és Keleti lakótelepi vizsgálatok-A kutatás módszertana és a minta néhány jellemzője [Research at the Husar and Eastern settlements in NyíregyházaMethodology of the research]. Acta Medicinae et Sociologica, 10(29), 8-18.

Tóth, G., Wachs, J., Di Clemente, R., Jakobi, Á., Ságvári, B., Kertész, J., \& Lengyel, B. (2021). Inequality is rising where social network segregation interacts with urban topology. Nature Communications, 12. https://doi.org/10.1038/s41467-021-21465-0

Varga, G. (2020). A roma népesség munkaerőpiaciterületi esélyei a Nagykanizsai járás területén [Regional labour market opportunities of the Roma population in the Nagykanizsa District]. Modern Geográfia, 3. https://doi.org/10.15170/MG.2020.15. 03.01

Wilkinson, R. G. (1996). Unhealthy societies: The afflictions of inequality. Routledge.

Wong, L. H., Pattison, P., \& Robins, G. (2006). A spatial model for social networks. Physica A: Statistical Mechanics and Its Applications, 360(1), 99-120. https://doi.org/10.1016/j.p

\section{About the Authors}

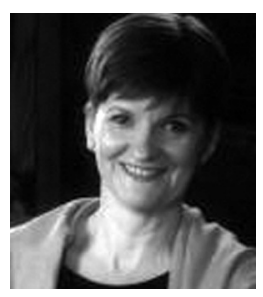

Éva Huszti is a sociologist and she works as an associate professor at the Institute of Political Science and Sociology of the University of Debrecen. Graduated in sociology (2003) and received her PhD in sociology in 2013. Her research interests include personal social network (quantitative and qualitative research methods), social integration, and ageing. 


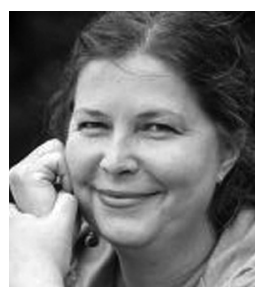

Fruzsina Albert is a research chair and head of the research department on families and social relations at the Institute for Sociology of the Centre for Social Sciences. She is also a professor of sociology at the Institute of Mental Health, Semmelweis University, Budapest. She is an expert at the European Social Policy Network. Her research interests include the study of interpersonal networks, including family and friendship ties by both quantitative and qualitative methods, social inclusion, gender, and ageing.

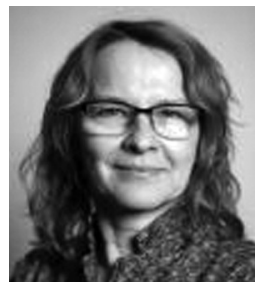

Adrienne Csizmady is the director of the Institute for Sociology at the Centre for Social Sciences (Hungarian Academy of Sciences Centre of Excellences), and associate professor of sociology at the Department of Sociology, Faculty of Humanities and Social Sciences, University of Szeged. Graduated in sociology (1995) and received her PhD in sociology in 2001. Her main research interests are urban social problems including social consequences of urban renewal, over-tourism, sustainable social environment, culture and heritage, suburbanisation, and integration strategies of people moving from town to country.

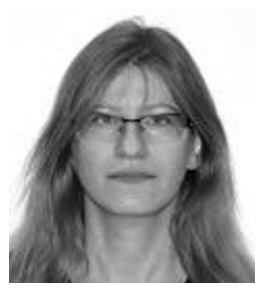

Ilona Nagy works as a demonstrator at Eötvös Loránd University (ELTE) and takes part in projects at the Centre for Social Sciences (Hungarian Academy of Sciences Centre of Excellences). She graduated as a geographer (MSc) specialised in urban and regional planning. At present, she studies mathematics, survey statistics, and data analysis at ELTE. Her main field of interest is the spatiality of social phenomena with an interdisciplinary approach and quantitative methodology.

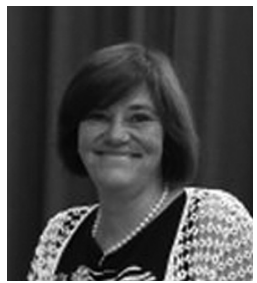

Beáta Dávid is a professor and director at the Institute of Mental Health, coordinator of the sociological doctorate program of mental health sciences, and vice-dean of Scientific and Educational Affairs at the Faculty of Health and Public Services, Semmelweis University, Budapest. She is research chair at the Centre for Social Sciences, president of the Hungarian Network for Social Network Analysis, and trustee board chair of Home Start Hungary. Her research interests include social network analysis, social capital, sociology of health, family, and ethnicity. 